\title{
Aesthetics and Incidence of the Rose Window in the Santos Juanes Church, Spain
}

\author{
J. M Molines Cano ${ }^{1,2}$, A. Almerich-Chulia ${ }^{2, *}$ \\ ${ }^{1}$ Department of History, Geography and Art, Universitat Jaune I, Spain \\ ${ }^{2}$ Department of Continuous Medium Mechanics and Theory of Structures, Universitat Politècnica de València, Spain
}

Received November 24, 2020; Revised January 15, 2021; Accepted February 17, 2021

\section{Cite This Paper in the following Citation Styles}

(a): [1] Molines Cano, J.M, Almerich-Chulia, A. , "Aesthetics and Incidence of the Rose Window in the Santos Juanes Church, Spain," Civil Engineering and Architecture, Vol. 9, No. 1, pp. 240 - 254, 2021. DOI: 10.13189/cea.2021.090120.

(b): Molines Cano, J.M, Almerich-Chulia, A. (2021). Aesthetics and Incidence of the Rose Window in the Santos Juanes Church, Spain. Civil Engineering and Architecture, 9(1), 240 - 254. DOI: 10.13189/cea.2021.090120.

Copyright@2021 by authors, all rights reserved. Authors agree that this article remains permanently open access under the terms of the Creative Commons Attribution License 4.0 International License

\begin{abstract}
Gothic architecture represents one of the most attractive moments of sacred architecture. In this context, some architectural elements act as leading characters, which are known as Gothic aesthetics. One of these is the rose window. It is a set element filled with marked symbolism that arouses considerable interest, and Spain has plenty of examples. In Valencia (Spain), the Santa Catalina or San Nicolás churches are extremely relevant temples. A coetaneous building of these churches is the Santos Juanes Royal Parish church, located next to the city's Central Market. Today it presents traces of this gothic origin, although the building has undergone complete Baroque modification, as evidenced by the huge "O" of San Juan. An element, according to all the traces, might be a big rose window that it is blocked today. Therefore, given the uncertainty of this particular element being present in the set of this church, this article aims to analyze the current aesthetics showing this well-known oculus in not only its historic and constructive forms, but also its structural one. To do so, we collected and analyzed historic and technical documentation, and studied the incidence of this element on the building's stability as a whole.
\end{abstract}

Keywords Rose Window, Mediterranean Gothic, Gothic Architecture, Gothic Aesthetic, Pushover Analysis

\section{Introduction}

The birth of Gothic architecture represents a radical change in Christian structures, a style that would mark the sacral architecture for centuries and coat temples majestically with a very similar, but distinctive, character to the Kingdom of Heaven by forming the Gothic aesthetics concept as we know it today. In this context, as Professor Cassinello reports in her studies, the historic construction of Gothic cathedrals is linked with the quest for a new message through light [1]. Therefore, the transition from Romanesque to Gothic implied a radical change in the heavy aesthetics of the former compared to the lightness of the latter. Accordingly, the rose window became one of the most interesting elements of medieval design. Applied since the Romanesque period, it was during this Gothic period when it acquired its real significance. Rose windows confer a distinct character and identity in church elevations, which vastly vary across Europe. By way of example, among many others, we find them in Notre Dame, Burgos, Barcelona, Majorca, and Valencia. A set of real architectural masterpieces with a particular mystic element and a marked esthetic component.

The rose window is set with a rich use of tracery in a rose-shaped form and plays a dual role: light up and protect temple interiors. Elements that draw a mysterious atmosphere as the Scriptures repudiate it as harmful [2]. An environment with an inner beauty filled with symbolism, where light, as a divine element, pierces the elements making it up with its rays to translate this experience into a place full of God [3]. However, without intending to delve further into the importance of light inside Gothic temples, it is interesting to note its impact 
when classifying Gothic temples into two large blocks. In his doctoral thesis, Zaragozá [4] defines it between "Mediterranean Gothic architecture" and its Gothic contemporaries in the rest of Europe. In the latter case, they are characterized by their structural lightness, which contrasts with that exhibited by the Mediterranean (Figure 1, Figure 2).

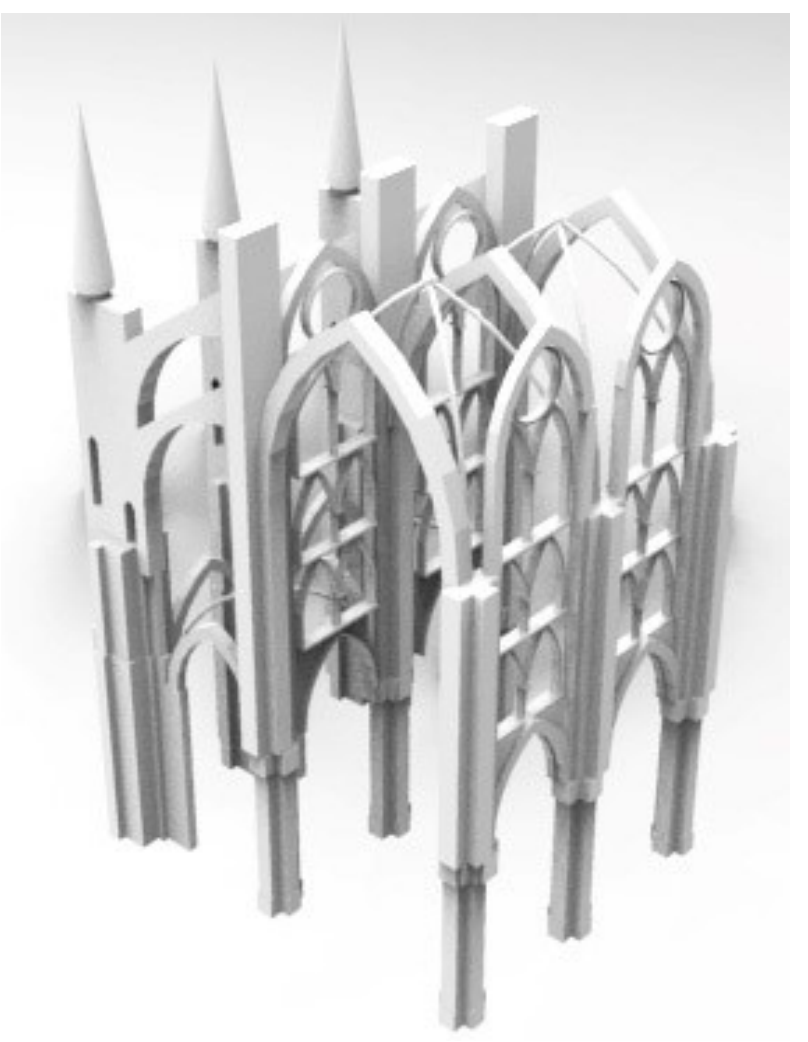

Figure 1. Central European Gothic structural form [5]

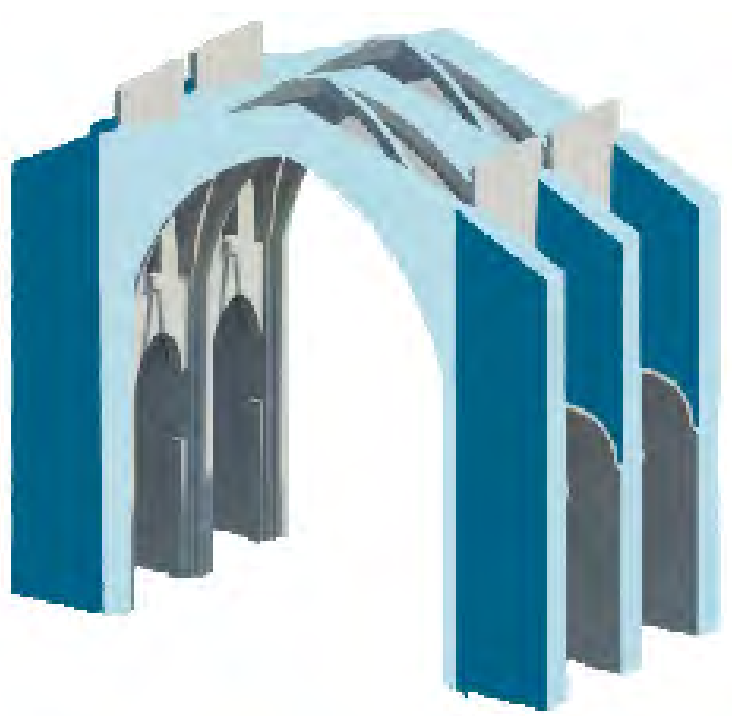

Figure 2. Structural plot of the Santos Juanes Royal Parish Church in Valencia, Spain.

After analyzing their peculiar characteristics, significant challenges remain for us all: why is there such a significant difference between these temples and their European counterparts? Why are Mediterranean cathedrals darker compared to the Sainte Chappelle or Notre Dame (in Paris) or (even) the León Cathedral? Several explanations have been proposed as grounds for these two forms of development. With the Mediterranean Gothic, we find defensive, economic, structural reasons, among others. However, as noted by Cassinello [6], the main reason for this very close relation lies between the seismic map of Europe (Figure 3) and the establishment of a common Gothic style. The dramatic experiences lived by the inhabitants in each region led them to consider some constructions based on typologies that had proved stable until that time as they understood that, even without current definitions, the earth occasionally shook. 


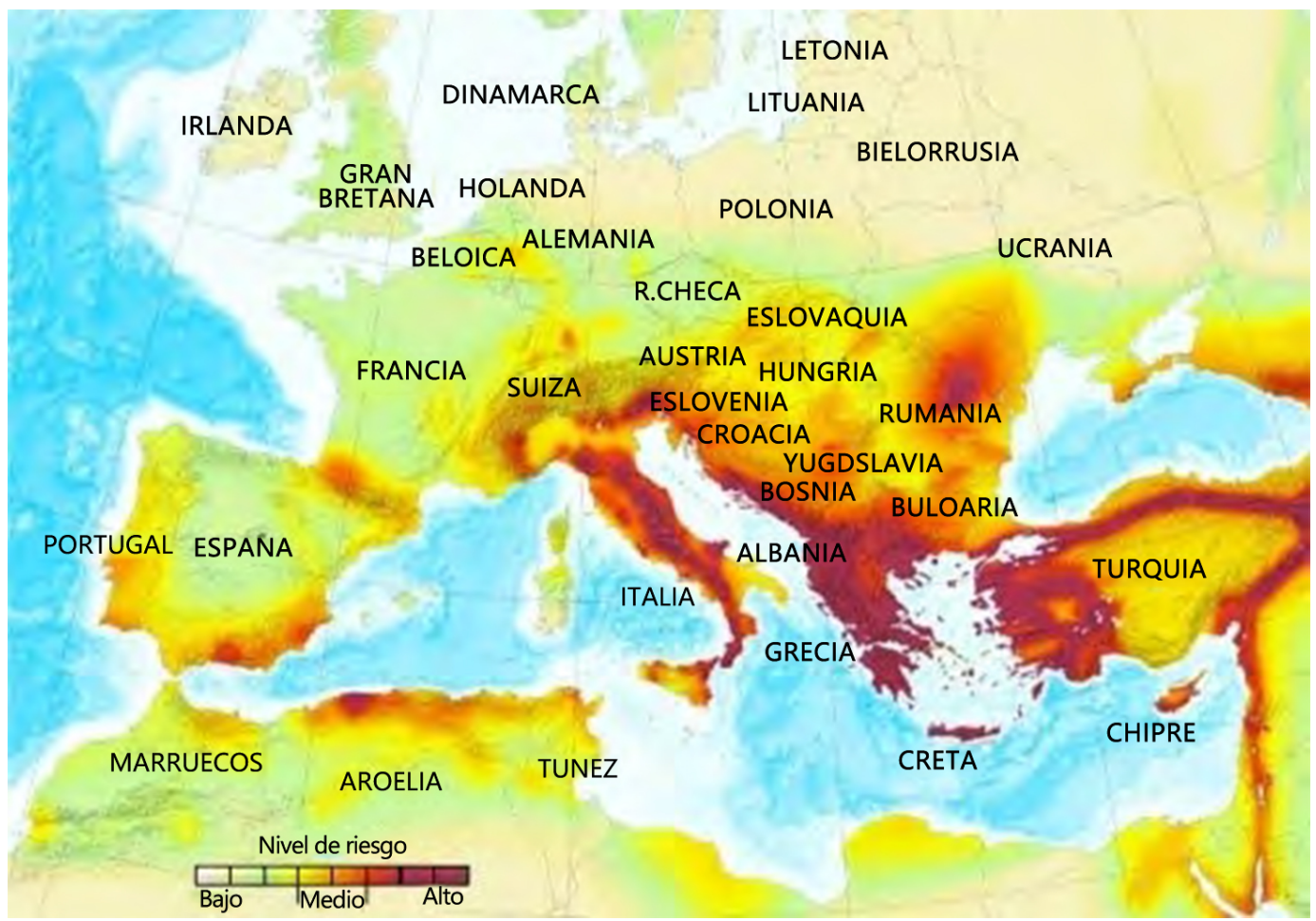

Figure 3. Seismic map of Europe [7]

This is possibly the reason why some peculiarities can be found in many Gothic churches in the Mediterranean Region, specifically in the Santos Juanes Royal Parish Church of Valencia, Spain. It is a temple with a mass stone structure character that struts the constructive set against seismic movements. This statement might explain why the famous "O" of San Juan is currently walled in (Figure 4). An element placed on the San Juan graveyard's façade formally reminds us what might have been a rose window (Figure 5) with unusual dimensions whose structural evolution toward its current aesthetics remains unknown.

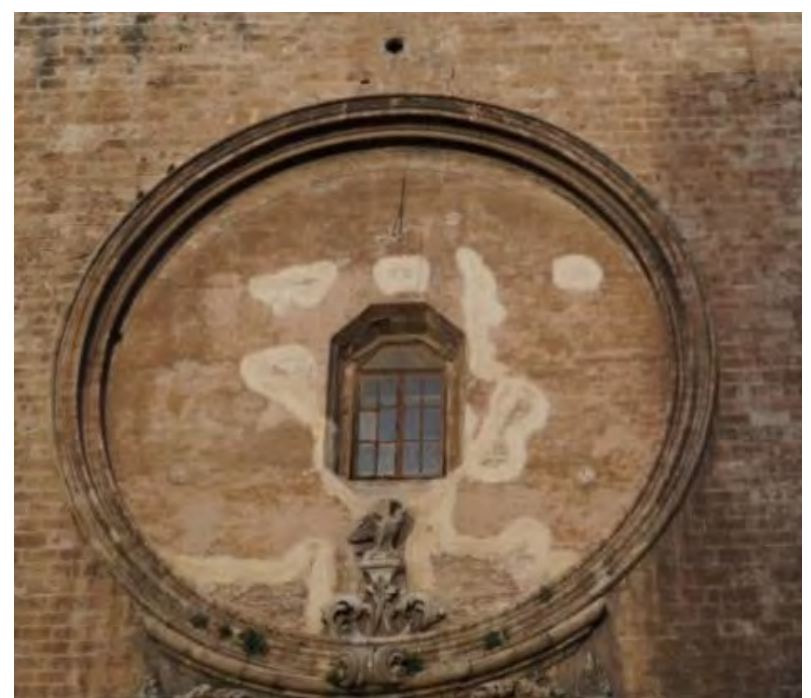

Figure 4. Detail of the "O" of San Juan
Therefore, this paper aims to reflect on the character that the rose window currently presents in an attempt to interpret the reasons why this element is practically walled in. For this purpose, a study of the documentation indicated its possible long-term evolution, while a structural analysis examined the impact that this rose window would have had on the whole set if this element had indeed been built.

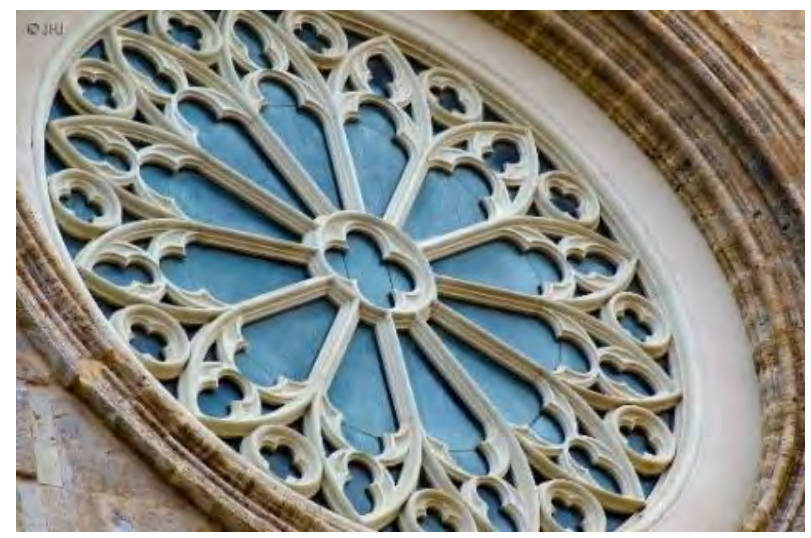

Figure 5. Rose window of the Santa Catalina Church [8]

\section{Structural Evolution of the Santos Juanes Royal Parish Church. The Construction of the " $O$ " of San Juan}

The Santos Juanes Royal Parish church is one of the most important ecclesiastical monuments in the city of 
Valencia (Spain). Located in the old "la Boatella" suburb, the church's configuration has changed it in terms of volume and style, influenced by the different currents in which it has been involved. Despite all this, the origin of the Santos Juanes Royal Parish church is imprecise. The scant documentation at that time, as well as the disparate references that appear in this regard, substantially hinder its exact temporal location.

Teixidor is one the authors who proposed an approximate dating of the first church and one of the most important historians of the city in the 18th century. This author referred to a parchment that recounts the donation of a mosque located in the la Boatella suburb after the Reconquest as the location of the new church [9].

Accordingly, King Jaume I's entering Valencia represented a radical change for the city, characterized by the introduction of a new culture, religion, population, etc. This change implied a new way of managing the city by parishes, which we currently understand as neighborhoods. This grouping was not random, but took advantage of the layout of the old mosques converted into Christianity. However, the transformation of the old mosques did not take place immediately. In the early days, the building itself was used and left unchanged, and sometimes only its consecration made it a Christian temple. Gradually adaptions were made in line with the spatial needs of each time.

One fact that can help us to determine and position the temple's original plan is the urban expansion that Valencia underwent in the mid-14th century, which increased its limits, and it was when a new wall was built. This urban development would have affected the temple surroundings and conditioned the building's characteristics in its early days [10]. In this way, the aforementioned urban intervention perpetrated and encouraged new buildings to be constructed in the Plaza de La Boatella surroundings, such as the Las Magdalenas convent, that of La Merced, and the adaptation of the Santos Juanes temple to the requirements of that time. The location of these new buildings, as well as that of the San Juan Cemetery, determined the position and configuration of the original plan by Galarza:

"The presbytery was sealed in two different and important ways: one without a typified chapel, rectangular; another, with a polygonal apse" [11].

Galarza reveals that the plan would consist of five modules and a straight apse, with no front façade other than two small entrances, as seen in Figure 6, which were subsequently bricked up. In this case, the main entrances located on the sides, symmetrically to the temple's longitudinal axis, became a typical solution of the Valencian churches converted after the Reconquest. This fact also implied no access from the main façade which, in most cases like this one, because a cemetery lay at the foot of the primitive construction.

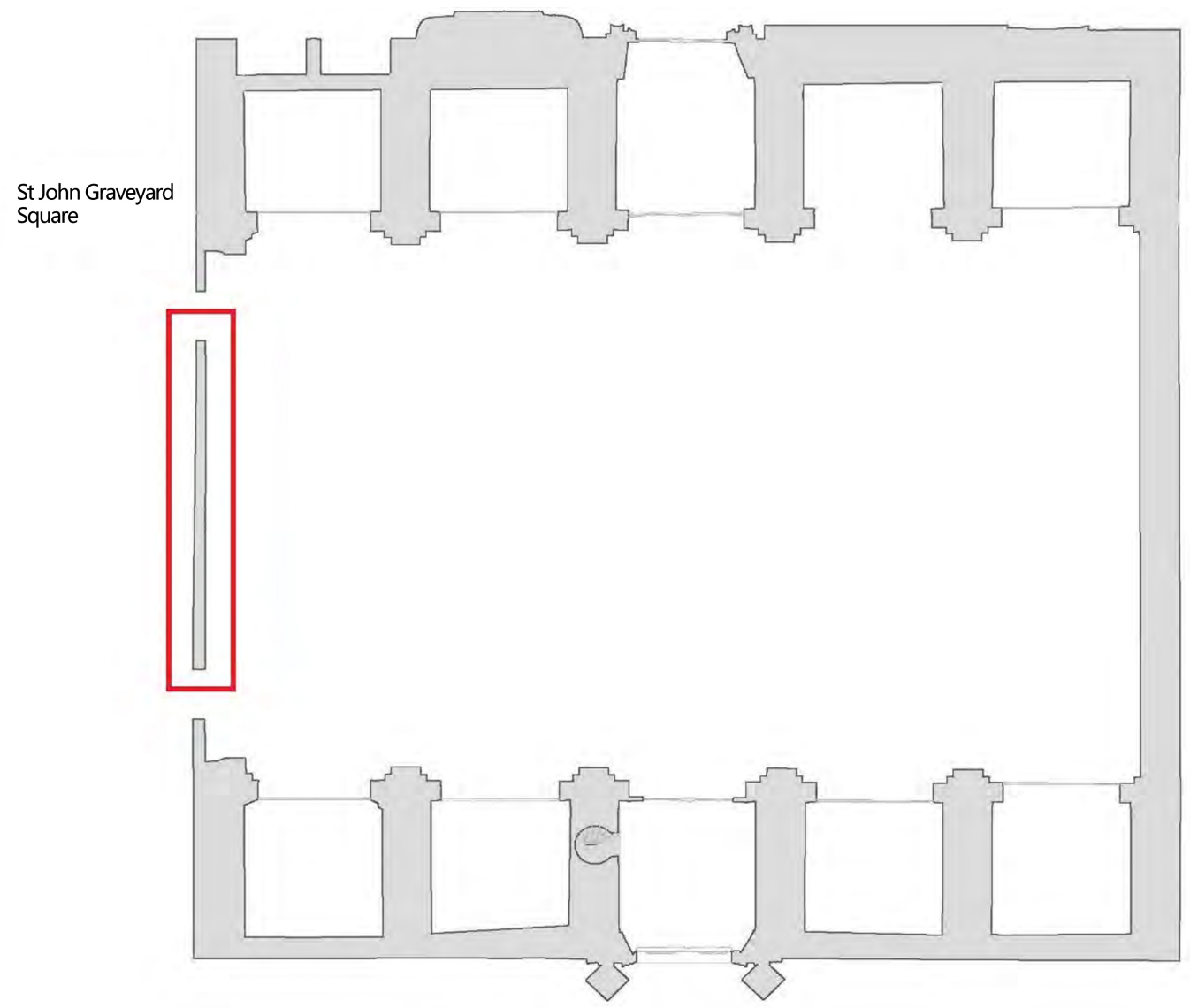

Figure 6. Hypothesis of the original church plan 
Nonetheless in the 18th century, the reforms made in accordance with the cemeteries regulation did away with that which existed at the foot of the temple and, consequently, led to the opening of the San Juan cemetery square to the natural transit. This notably impacted the temple because the small lateral accesses that originally existed (Figure 7) were walled off, which promoted the definitive construction of the well-known "O" of San Juan door:

"In 1787, a Royal Order was passed, which ordered the building of cemeteries outside city walls. This provision was reinforced by another order in 1804 about eliminating the moats adjacent to the religious buildings in the city." $[10]^{1}$

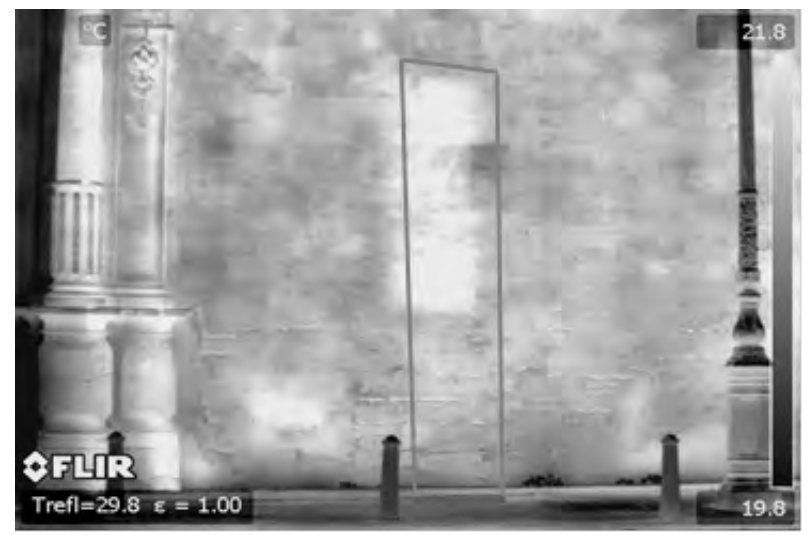

Figure 7. Thermographic image of the San Juan Cemetery façade

However, the non-existence of a main entrance door on the cemetery square façade right from the beginning does not justify blocking the enormous "O" of San Juan, which would have been foreseeably built in the first construction stage of the temple in the 14th century (Figure 8). As documents positioning it at a specific time are lacking, it is speculated that the "O" could have been a Gothic rose window built at this time to provide the temple with natural light, which occurs in the Santa Catalina Mártir Church in Valencia. One document that might support this hypothesis is "Relación del Viaje realizado por Felipe II, en 1585, á Zaragoza, Barcelona y Valencia” [12]:

"Finally, there are five most notable things in the town that are essential and are added to this description, denoted by these five letters: I, L, M, N and O. [...]

The Letter $\mathrm{O}$ is in San Juan is next to the Central Market, and it is a very big hole at the forefront of the church"2.

1 "En 1787 es promulgada una Reial Pragmática ordenant que els cementeris siguen construits fora dels murs de la ciutat, i aquesta disposició, reforçada per un altre de 1804, elimina els fossars adjacent als edificis religiosos ciutadans” (old Valencian language).

2 "Al postre cinco cosas hay en la ciudad que ponen por notables, que me

pareció de añadir aquí en esta descripción, y los exprimen con estas cinco letras I, L, M, $\mathrm{N}$ y O.....

...La letra O está en San Juan, junto al mercado grande, y es un agujero, en

la delantera de la iglesia, muy grande”. (old Castilian language).

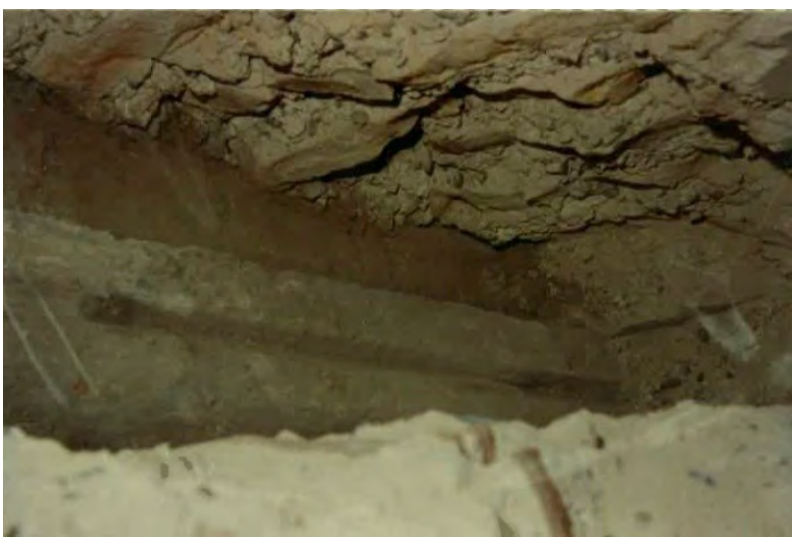

Figure 9. Detail of the central oculus groove

In the "quantitate animae" book, a set of patterns of beauty appear about geometric regularity. Geometrically speaking therefore, the circle is presented as one of the most beautiful elements, where no angle, unlike the triangle, breaks the continuity of the circumference [13]. Notwithstanding, a more detailed study on the "O" of San Juan by Estellés suggests the opposite. Samples taken from the current oculus led him to conclude that there were no remains of any Gothic tracery within the frame 
located in the center of the keystones [14]. Consequently if the initial purpose of master builders was to build the biggest Gothic rose window in the Mediterranean Region, something cut their ambitions short.

\section{Influence of the " $O$ " on the Church's Structural Resistance}

The origin of the "O" of San Juan presents considerable uncertainty. Hence this study intends to figure out the impact that the design for a rose window would have had, if indeed built, on the whole set of this church. For this study, two 3D calculation models were built: one capable of reproducing the church's current characteristic with the walled "O"; another to consider Gothic rose window tracery.

The analysis took into account the importance of seismic load in Mediterranean Europe. To evaluate the church's seismic performance, a nonlinear "push-over" [15] analysis was performed. Moreover, the way stone and brick behaved was simulated to the "damage model", one of the most rigorous methods for reproducing the response of fragile materials.

To create the 3D calculation model, the "Bovedas 3D" [16] software was used. This tool consists of a CAD plug-in designed specifically for modeling this type of historic structures. It especially focuses on obtaining the easy meshing of geometric elements. The 3D model was then transferred to the ANGLE analysis software [17].

\subsection{Constitutive Model}

In this case, the stonework to be analyzed was built with ashlar masonry and the the interior was filled with mortar. This confers lack of continuity between joints, which can be viewed from the outside. Given this structural arrangement, the isotropic damage continuous model was used for modeling material behaviors.

Damage mechanics introduces changes into the material at the microstructural level through internal variables. These variables modify the influence of the material behavior history on the evolution of stresses. The appearance of fissures and their evolution over time are described as the damaged point's trajectories.

Cracks are represented as an effect of local damage, characterized according to compressive and tensile strength from knowing not only the material's parameters, but also the functions controlling crack evolution according to the successive strain state at all damaged points.

A structural analysis was performed using the finite element nonlinear regime ANGLE software, where the application for isotropic damage developed by [18] was added.

The followed model focuses on the difference in the compression and traction behavior of such materials, the degradation of their stiffness due to the stress level, and the effect on the response depending on the size of the mesh used in finite element modeling. All this provides a correct model of a materials's nonlinear behavior [5].

In this context, material with a damage level is considered. This degradation is represented as the voids that the material has supported. By taking $S$ as the estimated total surface and $\mathrm{S}^{\prime}$ as the effective resistant area, then (S-S') is the surface of the hollows in masonry. Consequently, damage variable " $\mathrm{d}$ " is defined as:

$$
d=\frac{S-S^{\prime}}{S}
$$

If we consider a pulling uniaxial state, as shown in Figure 10, then nominal stress $\sigma$ and real stress $\sigma^{\prime}$ are: (a)

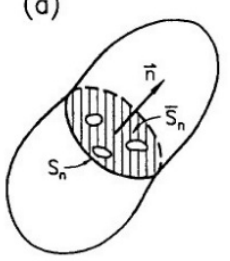

(b)
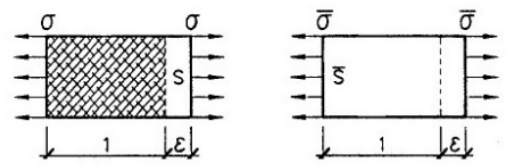

Figure 10. Pulling uniaxial state [5]

The relation between Cauchy's tension and the effective tension acting on the real effective section can be calculated by the equilibrium condition:

$$
N=S \cdot \sigma \quad N=S^{\prime} \cdot \sigma^{\prime}
$$

Therefore

$$
\begin{aligned}
& S \cdot \sigma=S^{\prime} \cdot \sigma^{\prime} \\
& \sigma=(1-d) \cdot \sigma^{\prime}=(1-d) \cdot E \cdot \varepsilon
\end{aligned}
$$

Graphically speaking:

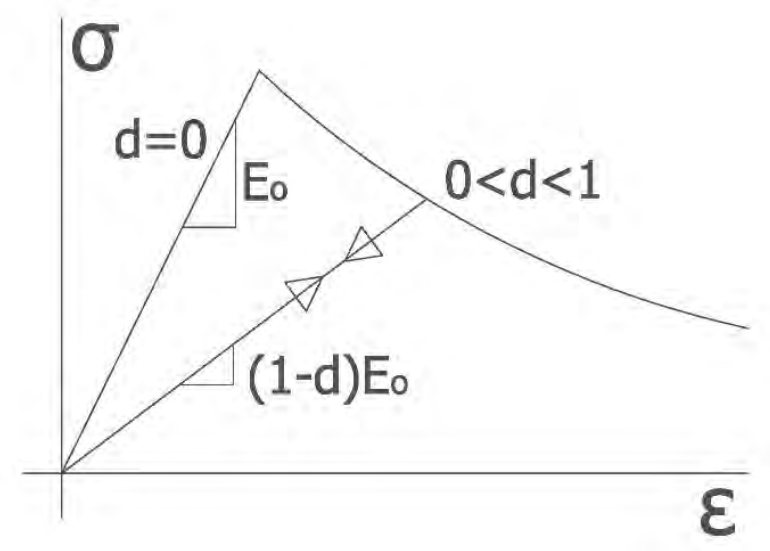

Figure 11. Damage Model [5]

Index $\mathrm{d}$ indicates the material's degree of deterioration $(0 \leq \mathrm{d} \leq 1)$, where 0 is the undamaged material and 1 is the damage of the rugged area. Therefore as shown in Figure 9 , it means a reduction in stiffness that is proportional to 
(1-d) in the material's mechanical behavior. Consequently, this index is sufficient to represent the behavior of such material, mainly brick or stone.

By extending this relation to the total vector of stresses, we obtain:

$$
\left[\begin{array}{c}
\sigma_{X} \\
\sigma_{y} \\
\sigma_{z} \\
\tau_{X} \\
\tau_{y} \\
\tau_{z}
\end{array}\right]=(1-d) \cdot[D] \cdot\left[\begin{array}{c}
\varepsilon_{X} \\
\varepsilon_{y} \\
\varepsilon_{Z} \\
\gamma_{X} \\
\gamma_{y} \\
\gamma_{z}
\end{array}\right]
$$

where $\mathrm{D}$ is the elasticity matrix for the isotropic material. During the MEF calculation process, constitutive matrix $\mathrm{D}$ 'is calculated as:

$$
D^{\prime}=(1-d) \cdot D
$$

In addition, the damage variable at each instant of the loading and deformation process is defined as:

$$
d=1-\frac{r_{0}}{r} \exp \left[A \cdot\left(1-\frac{r_{n}}{r}\right]\right.
$$

where $\mathrm{r}=\max \left\{\mathrm{r}_{0}, \mathrm{r}_{\mathrm{n}}\right\}$ and parameter $\mathrm{A}$ depends on the energy dissipated per unit volume for a uniaxial tension process [19].

Of the advantages offered by this damage formulation, the most advantageous one is its simple calculation for other cracking models because it does not require a special algorithm that integrates the constitutive equations of elastoplastic models. In this case, the model variables are the material's characteristics: modulus of deformation; Poisson's ratio; tensile and compressive strength; fracture energy.

\subsection{Seismic Action}

A pushover analysis (PA) is often employed to determine the seismic vulnerability of constructions. This method uses a simplified nonlinear technique and produces good results compared to reality. The PA method, developed by Freeman in 1998 [20], is characterized by graphic methods by comparing a structure's capacity to the demand caused by the ground in the event of an earthquake. Seismic action is added by subjecting the structure to horizontal loads $\mathrm{Fi}$, which are increased until the structure's maximum capacity is reached. This study employs modal load pattern distribution. A capacity curve that relates the responses of the base, basal shear $\mathrm{V}_{\mathrm{b}}$, and movements $\mathrm{D}$ at the structure's upper level represents the structural response capacity (Figure 12).
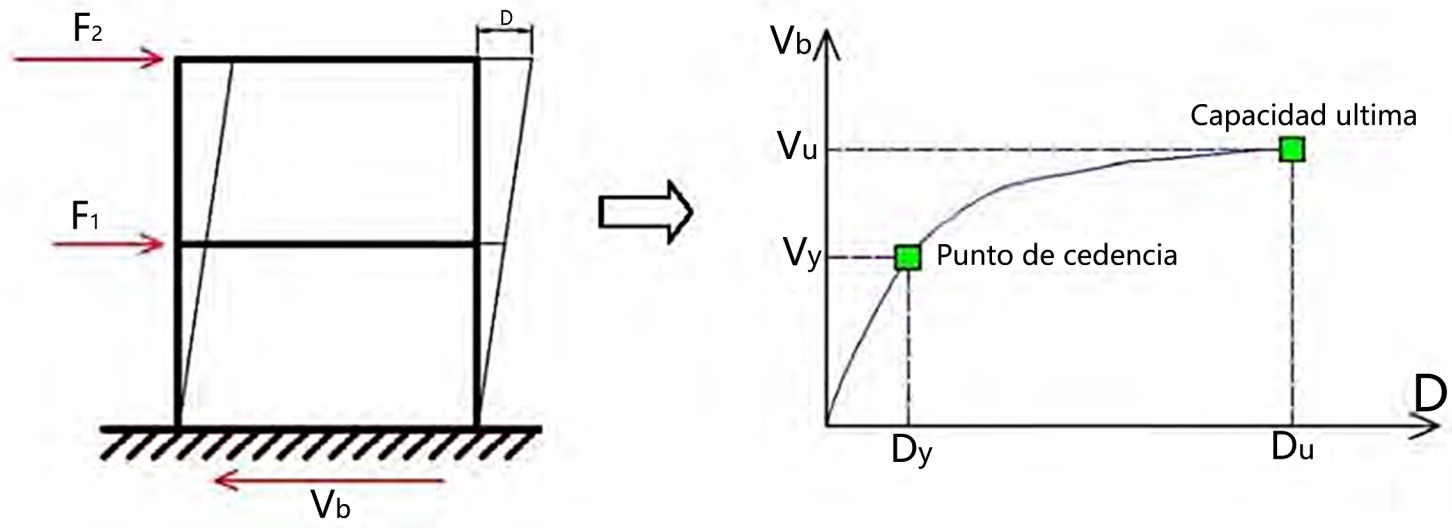

Figure 12. Load pattern used by the PA method and capacity curve [20] 
In this specific case, according to Spanish standard NCSE-02, Valencia seismic demand is defined according to the return period. There are two significant demand points: the first corresponds to a design spectrum for a return period of 475 years, while the second involves a return period of 950 years.

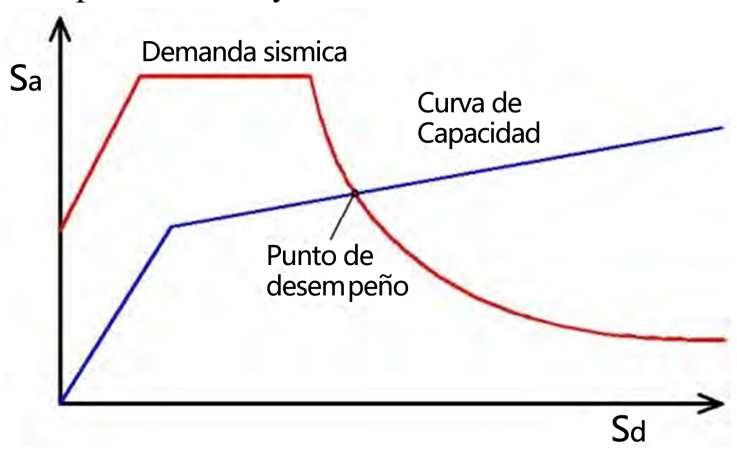

Figure 13. Performance Point [20]

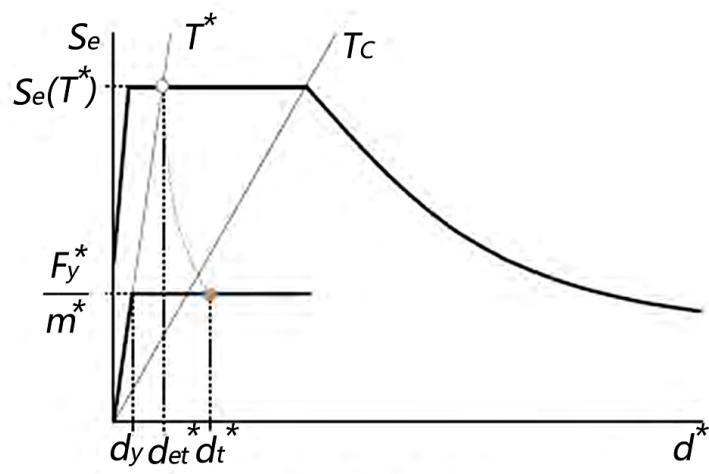

a) Short term Period
The intersection between the structural response capacity and seismic demand is called the Performance Point. It evaluates the limit behavior of structural elements according to the expected seismic demand (Figure 13).

Eurocode 8 defines the Performance Point for a short-term or long-term structure as indicated in the figure 14.

Currently, some methods relate the capacity curve and demand curve to obtain the Performance Point [20]. To compare both curves, and demand and capacity, they have to be transformed into a homogeneous format: Acceleration-Displacement Response Spectrum (ADRS).

Subsequently, this curve is simplified by bilinear tracing, which must meet the following requirements: the area below both curves must be the same; the maximum displacement coordinates must coincide; the slope of the initial branch must be the same on both curves.

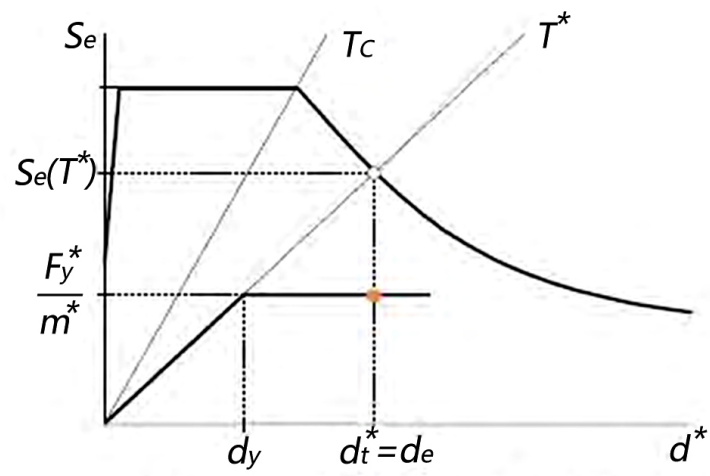

b) Medium and long-term Periods

Figure 14. Indicative charts for Performance Points [21] 
The bilinear graph is defined completely by two points that correspond to a spectral displacement $\left(\mathrm{S}_{\mathrm{d}}\right)$ at the end of the elastic branch $\left(\mathrm{S}_{\mathrm{d} 2}\right)$ and a spectral displacement at the end of the plastic branch $\left(\mathrm{S}_{\mathrm{d} 4}\right)$, which will be the damage thresholds (Figure 15).

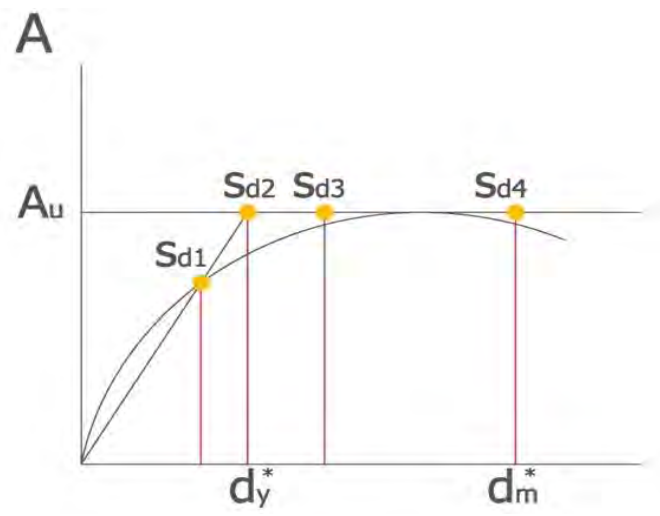

Figure 15. Damage thresholds [21]

Table 1. Damage thresholds Ranking

\begin{tabular}{|c|c|}
\hline Damage thresholds & Definition \\
\hline Negligible & $\mathrm{Sd} 1=0,7$ Dy \\
\hline Moderate & $\mathrm{Sd} 2=\mathrm{Dy}$ \\
\hline Serious & $\mathrm{Sd} 3=\mathrm{Dy}+0,25(\mathrm{Du}-\mathrm{Dy})$ \\
\hline Collapsed & $\mathrm{Sd} 4=\mathrm{Du}$ \\
\hline
\end{tabular}

Table 2. Damage Levels

\begin{tabular}{|c|c|c|}
\hline Damage Level & Lower Threshold & Upper Threshold \\
\hline Negligible & Origin & Sd1 \\
\hline Moderate & Sd1 & Sd2 \\
\hline Substantial & Sd2 & Sd3 \\
\hline Serious & $\mathrm{Sd} 3$ & $\mathrm{Sd} 4$ \\
\hline Collapsed & $\mathrm{Sd} 4$ & ------ \\
\hline
\end{tabular}

According to RISK-UE [22], a damage thresholds ranking is defined (Table 1 , Table 2).

\subsection{Mechanical Characteristics of Materials}

The characterization and identification of the material found in the church were performed as follows: on the one hand, by the investigations carried out by various authors on other buildings with similar material and construction characteristics; on the other hand, studies conducted on the influence of variation in the materials' different mechanical characteristics on structural behavior, specifically against horizontal forces.

Having studied the data in-depth, and given the significant differences in this topic and the impossibility of obtaining compelling results from the used material, the following range of safe common values was taken.

Table 3. Mechanical properties of materials

\begin{tabular}{|c|c|c|c|c|c|}
\hline Material & $\mathrm{D}\left(\mathrm{t} / \mathrm{m}^{3}\right)$ & $\mathrm{E}\left(\mathrm{N} / \mathrm{mm}^{2}\right)$ & fc $\left(\mathrm{N} / \mathrm{mm}^{2}\right)$ & $\mathrm{Ft}\left(\mathrm{N} / \mathrm{mm}^{2}\right)$ & $\mathrm{Gf}+\left(\mathrm{Nmm} / \mathrm{mm}^{2}\right)$ \\
\hline Ashlar & 2.2 & 7500 & 12.00 & 0.35 & 0.30 \\
\hline
\end{tabular}

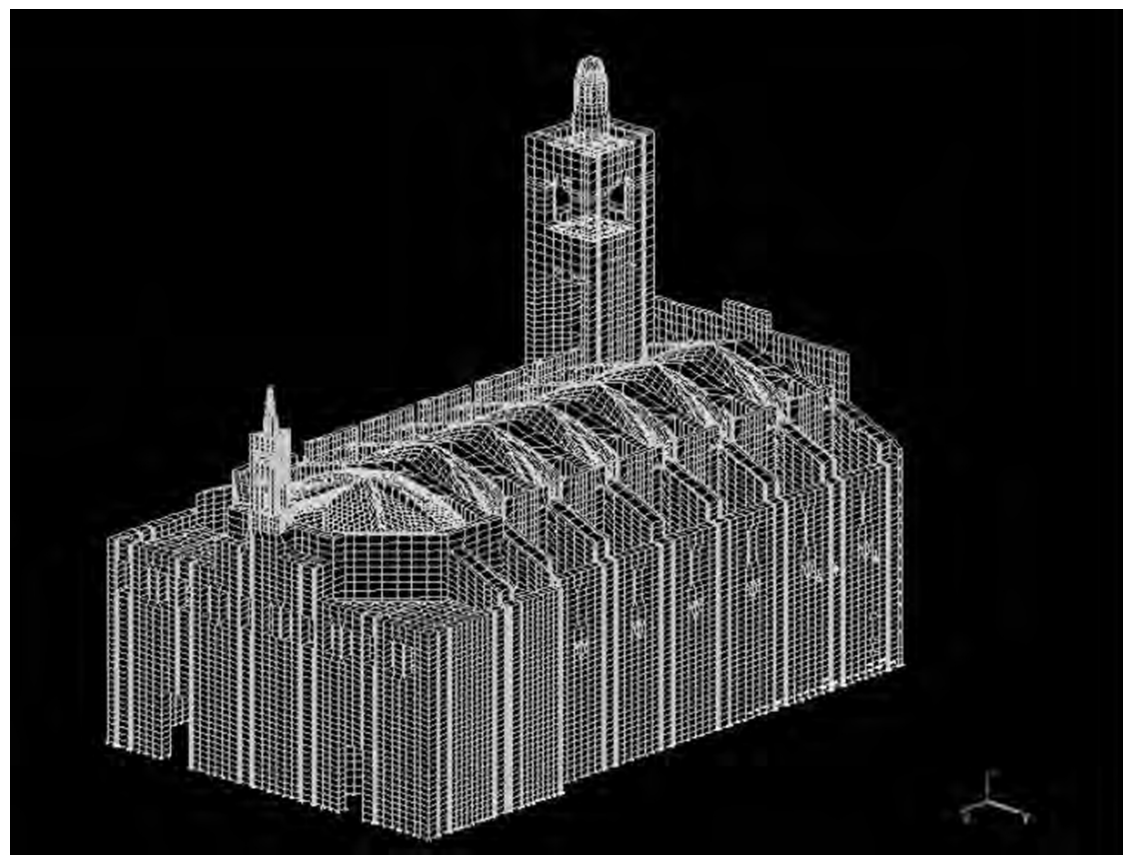

Figure 16. Overall view of the building with the walled "O". 


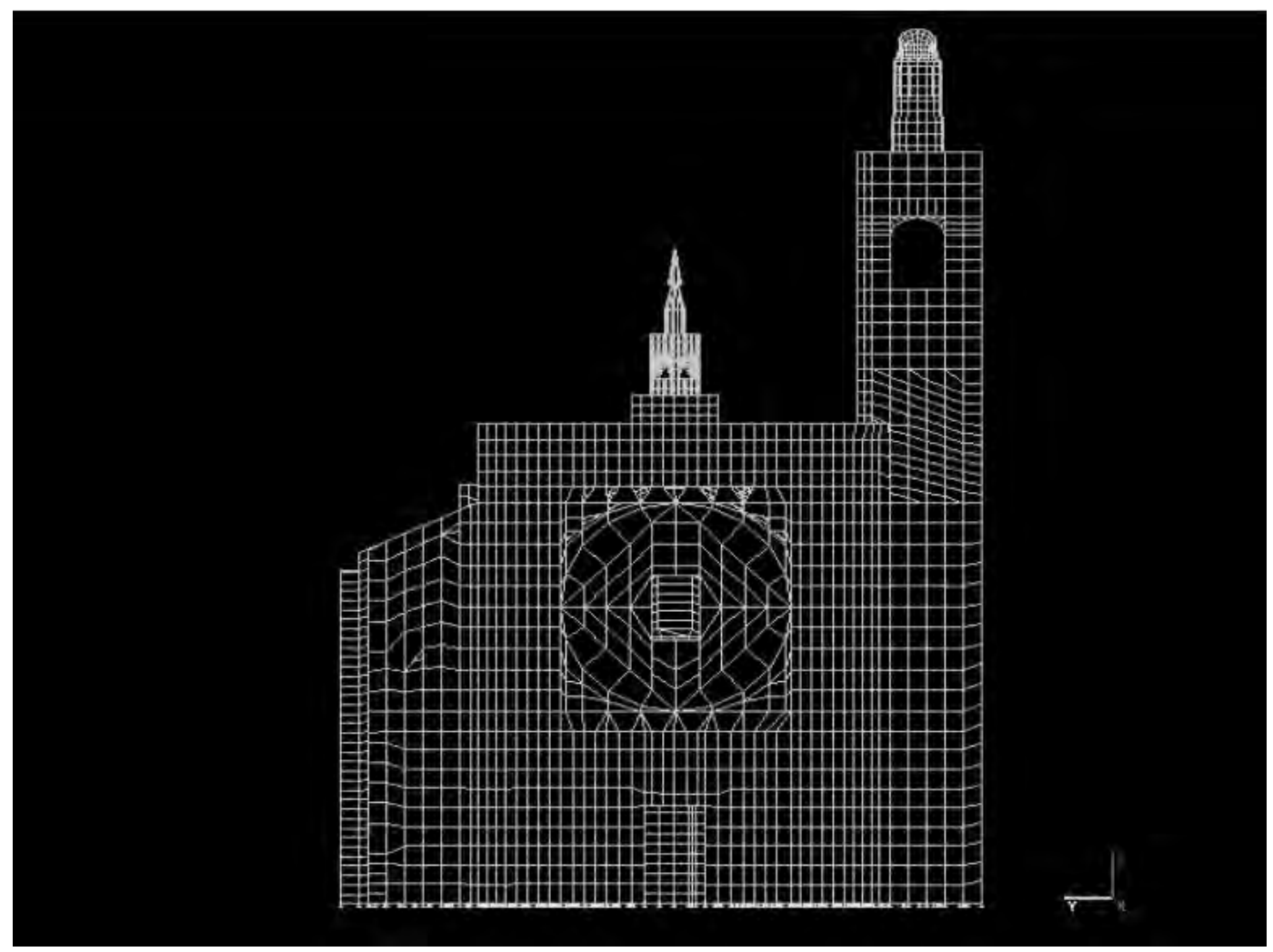

Figure 17. Façade with the walled "O"

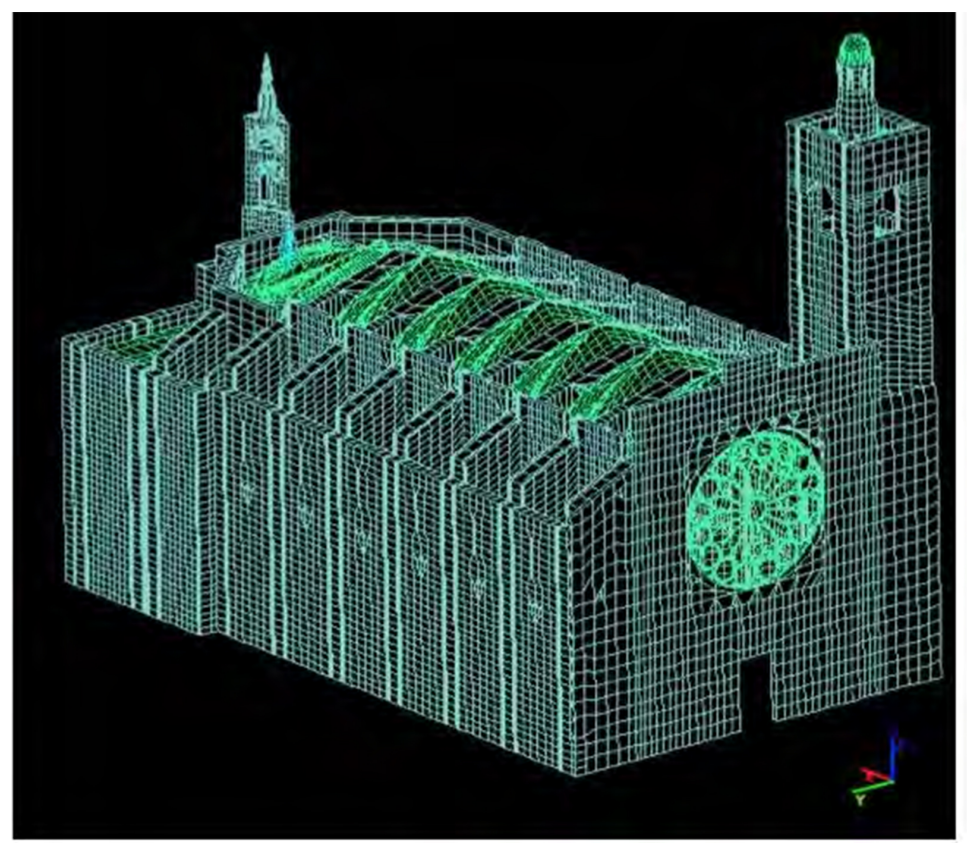

Nodes 96866

Solids_49298

Tetrahedrons 2893

Hexahedrons_44262

Layers 19711

No.of Equations_353385

Figure 18. Overall view with the rose window 


\subsection{Structural Model}

Two 3D calculation models were created. The first model reproduced the current situation, including the famous the "O" of San Juan as it now exists. This allowed us to consider the incidence of dynamic loads on the central nave, side chapels and façades, and also on the apse (Figure 16, Figure 17).

The second model (Figure 18) dealt with analyzing the effect of removing the current false wall. It was replaced with Gothic tracery that was as similar as possible to what could have been built during that period.

\subsection{First Model: The Building with the Walled " $O$ ".}

The initial check made by the first considered model was the correct transmission of vertical forces to the model's base. This showed that the assembly correctly transmitted loads to the base by concentrating the maximum compressive stresses at the zero level. However given the increased bell tower weight, higher stresses were observed in this area compared to the rest of the building (Figure 19).

In the first load steps of the nonlinear static analysis, we see that the main church structure was not affected, at least not in a generalized manner (Figure 20).

\section{Analysis Results}
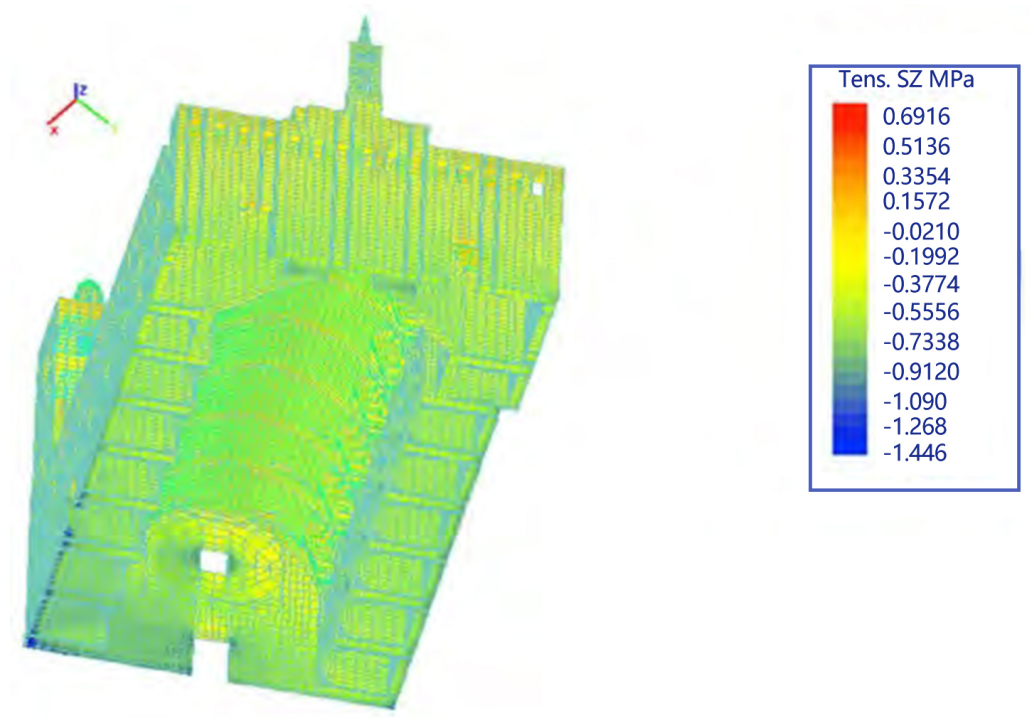

Sx: $1.31 /-1.77$

Sy: $1.73 /-2.48$

Sz: $0.69 /-1.45$

Figure 19. Stresses isovalues for $\mathrm{Z}$ tensions vs. gravity loads
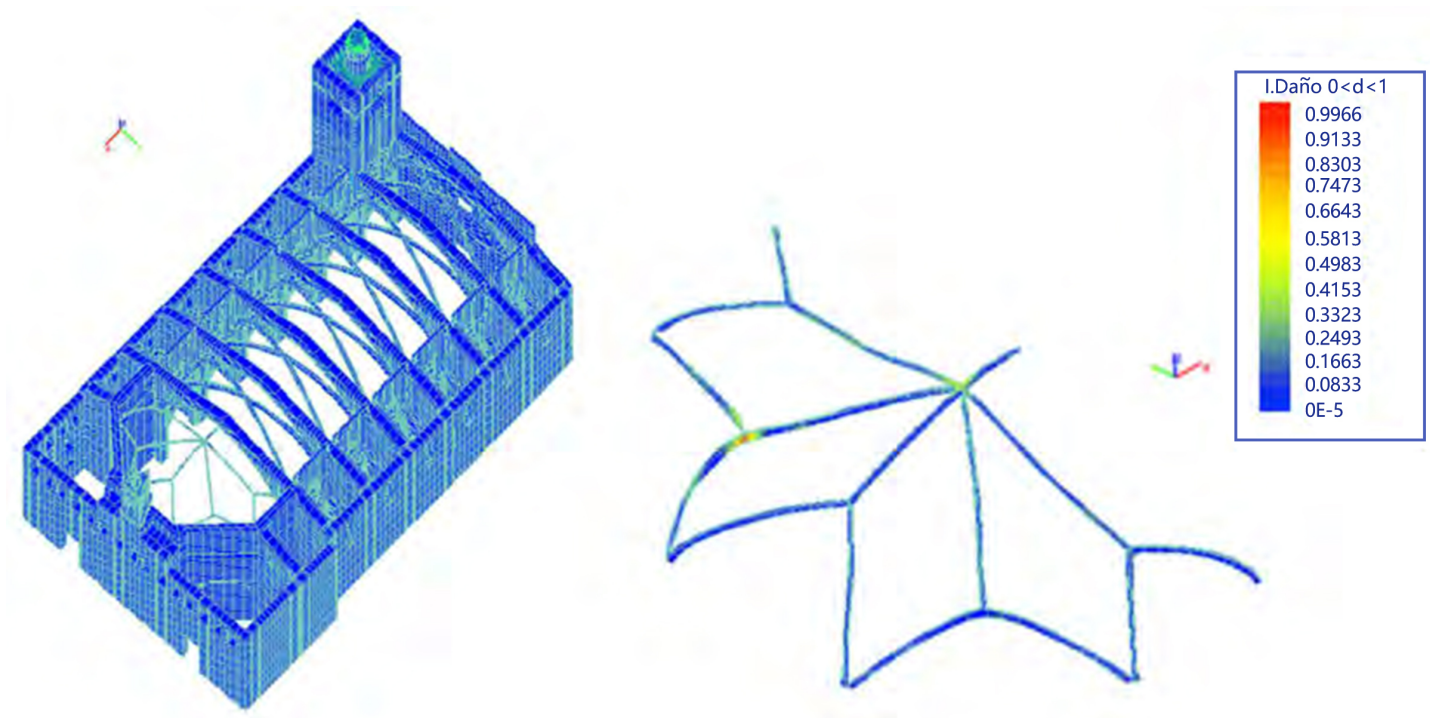

Figure 20. Damage index for the $100 \%$ gravitational load 

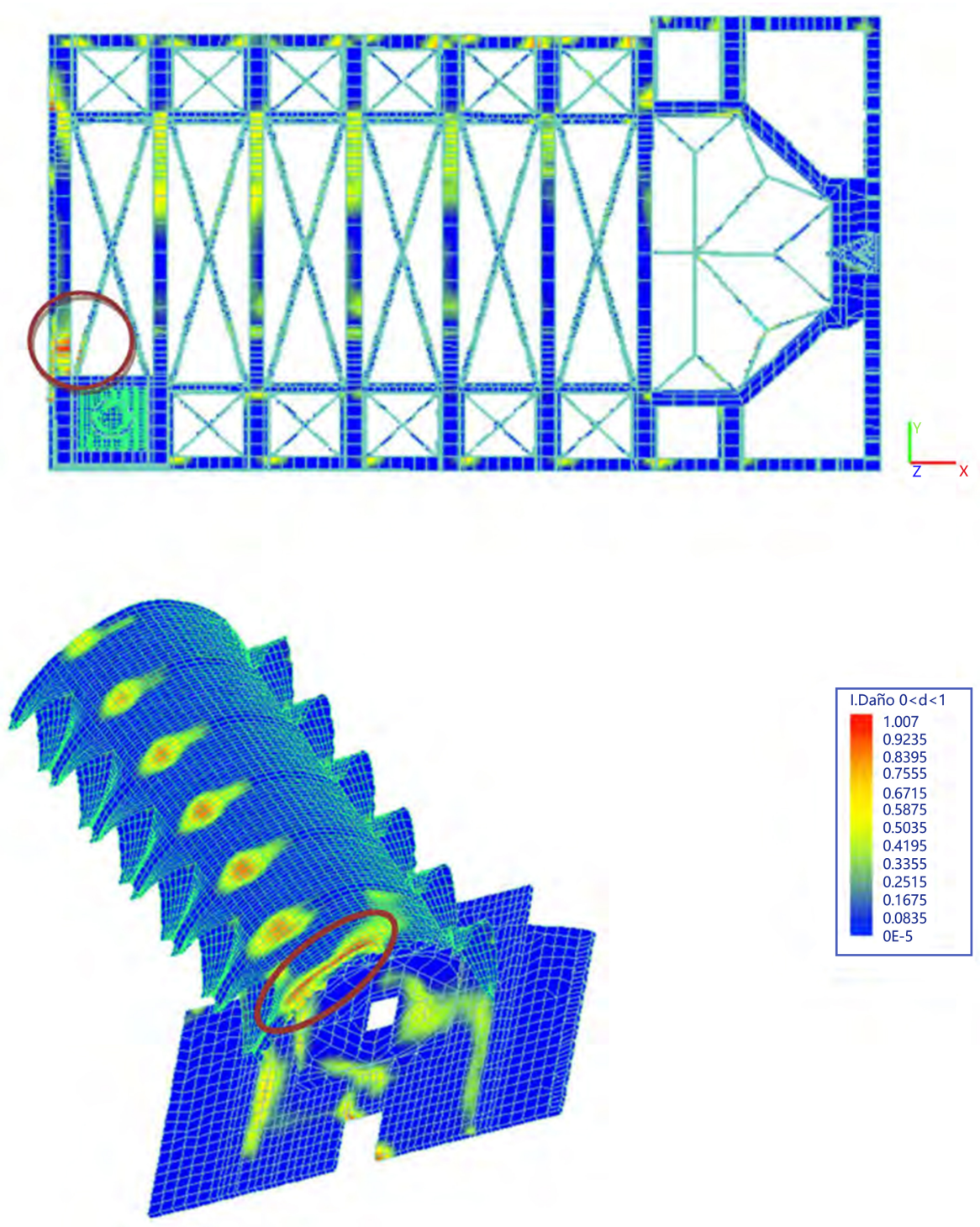

Figure 21. Damage index. Plan and 3D view

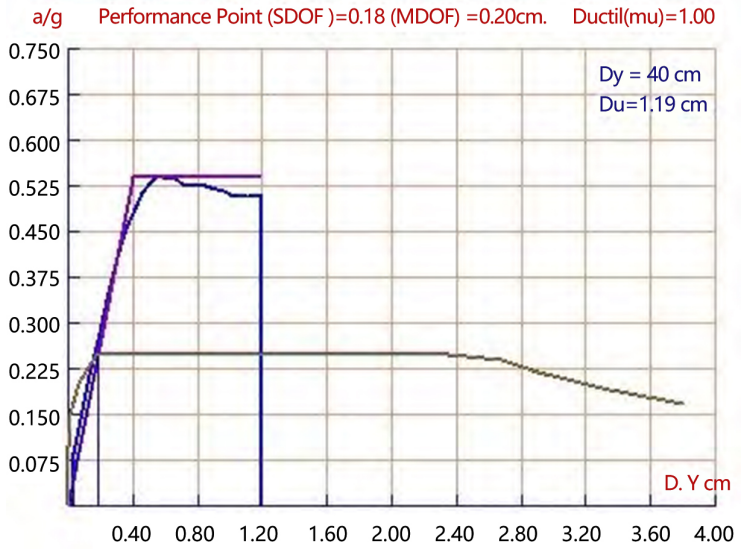

Figure 22. Performance point determination. The model with the walled "O"

However, the model exhibited significant damage with the $100 \%$ gravitational load and the $32 \%$ seismic load in the "Y" direction. The most damaged area lay close to the main façade (Figure 21).

When applying an earthquake on the Y-axis for a return period of 950 years, the maximum deformation of $\mathrm{Y}$ was $0.2 \mathrm{~cm}$ and the Performance Point was 0.18 (Figure 22).

We observed that damage concentrated in the areas near the bell tower and the "O" façade was the most damaged area. However, the structure did not collapse (Figure 23).

After the present study, the aim should be for the bell tower to play a key role in the façade, even though it was an additional element that was later inserted into the original set many years later. This implies a large load on the façade, which did not occur with some contemporary buildings where the bell tower, by being located far from the main façade, allowed a Gothic oculus to be included. One such example is the Santa Catalina Church in Valencia (Figure 24). 

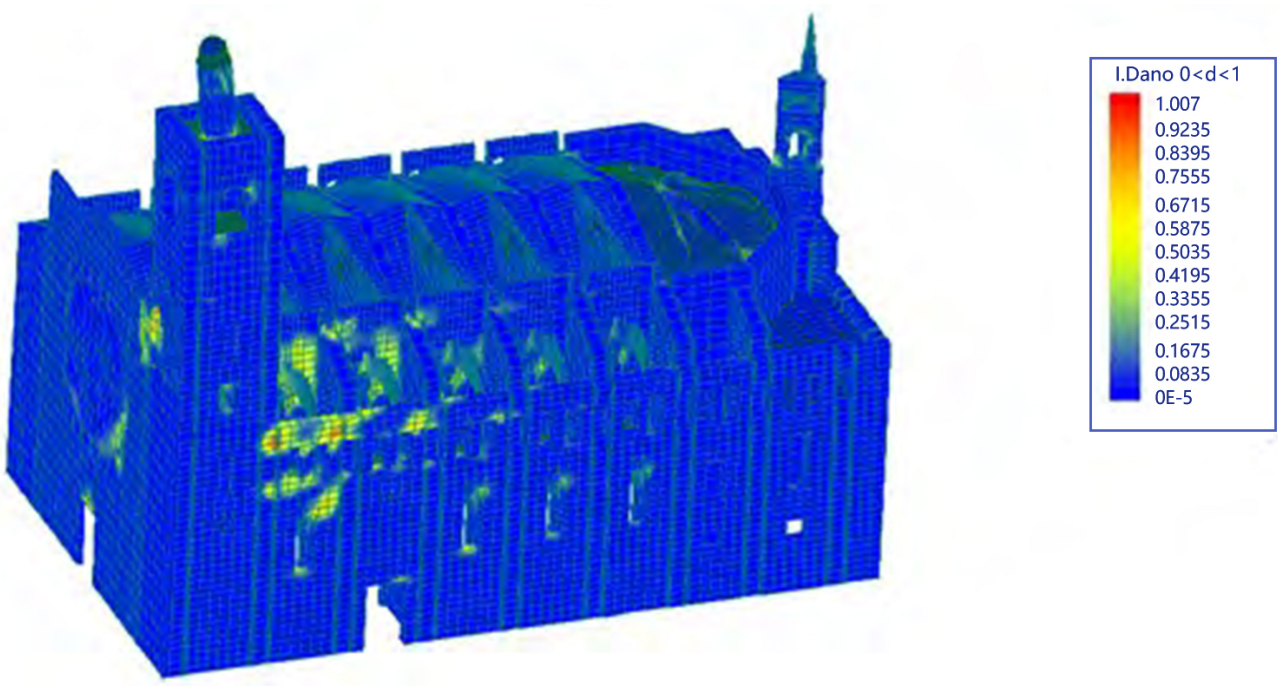

Figure 23. Damage index for the walled "O" model in the second 2.2.

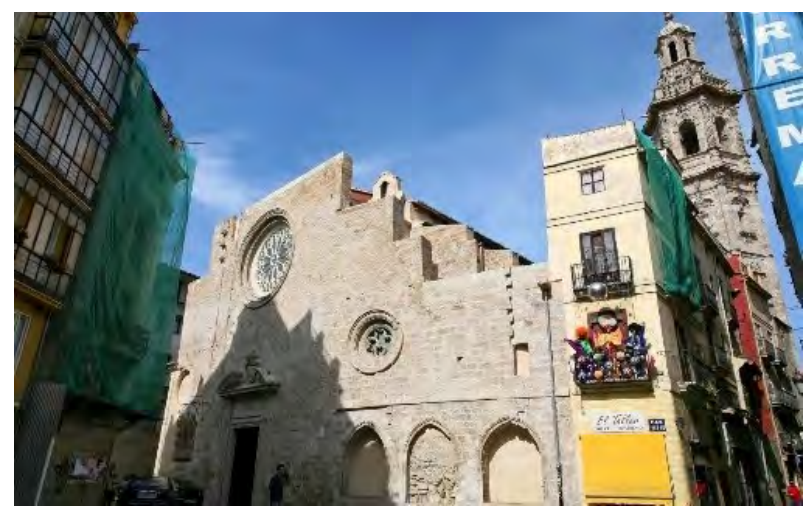

Figure 24. Santa Catalina Church (Valencia). [23]

It is also very interesting to study the correlation of the results obtained by our analysis with reality as shown in Figure 25, which is a view of the façade interior. According to our computational models, the major crack that we found coincides with the damaged area.

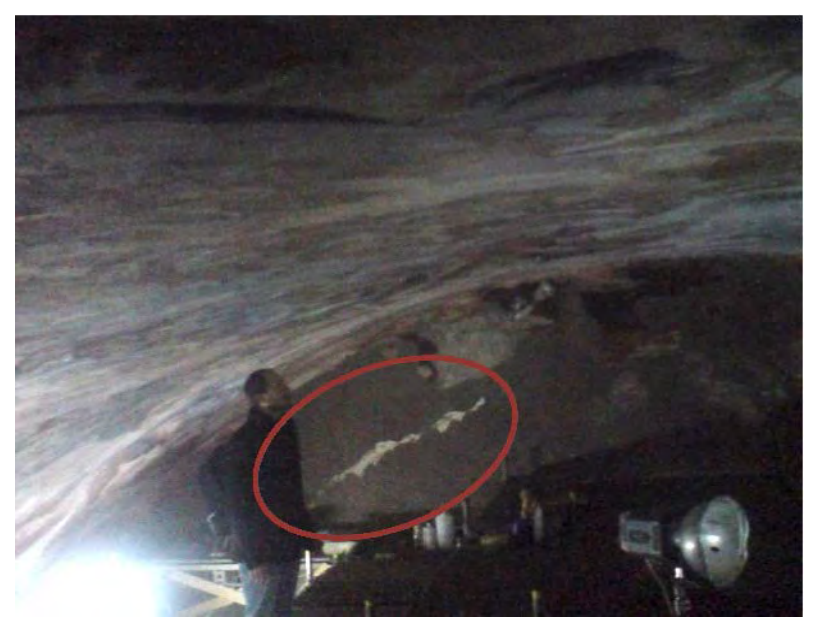

Figure 25. Interior façade view. Crack

After detecting a crack and its correspondence to the calculation model, crack size was analyzed. For this purpose, a thermographic camera was used, which verified that the detected crack penetrated the entire enclosure as the interior façade values contrasted with the heat loss that took place in the crack (lighter color) (Figure 26).

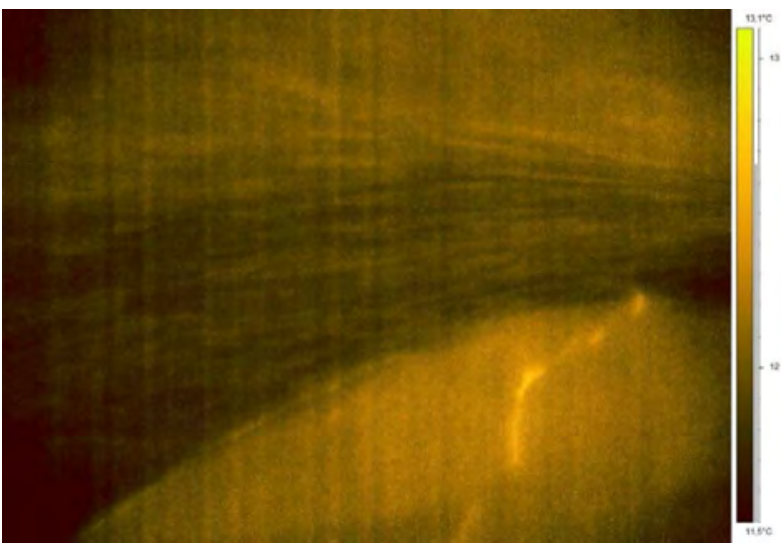

Figure 26. Thermographic camera. Crack

These conclusions corroborate the data obtained by Estellés in the 1990s about the state of the church and the weaknesses that it presents. He states that the building is in perfect condition, its main structure is not damaged, and the only considerable vertical downward shifts appear on the "O" façade near the bell tower. He also states that these displacements are due to the increased load that the bell tower had on the building, which was built many years later [14].

\subsection{Second Model: The Building with a Rose Window}

In the second model, the wall covering of the "O" was replaced with Gothic tracery. Greater façade weakening was observed from the first loading steps. Complete damage appeared with the $100 \%$ gravitational load and the $26 \%$ seismic load in the first steps when seismic loads were applied (Figure 27). When we compared it to the previous model (Figure 21), it indicated the model's greater seismic vulnerability. 


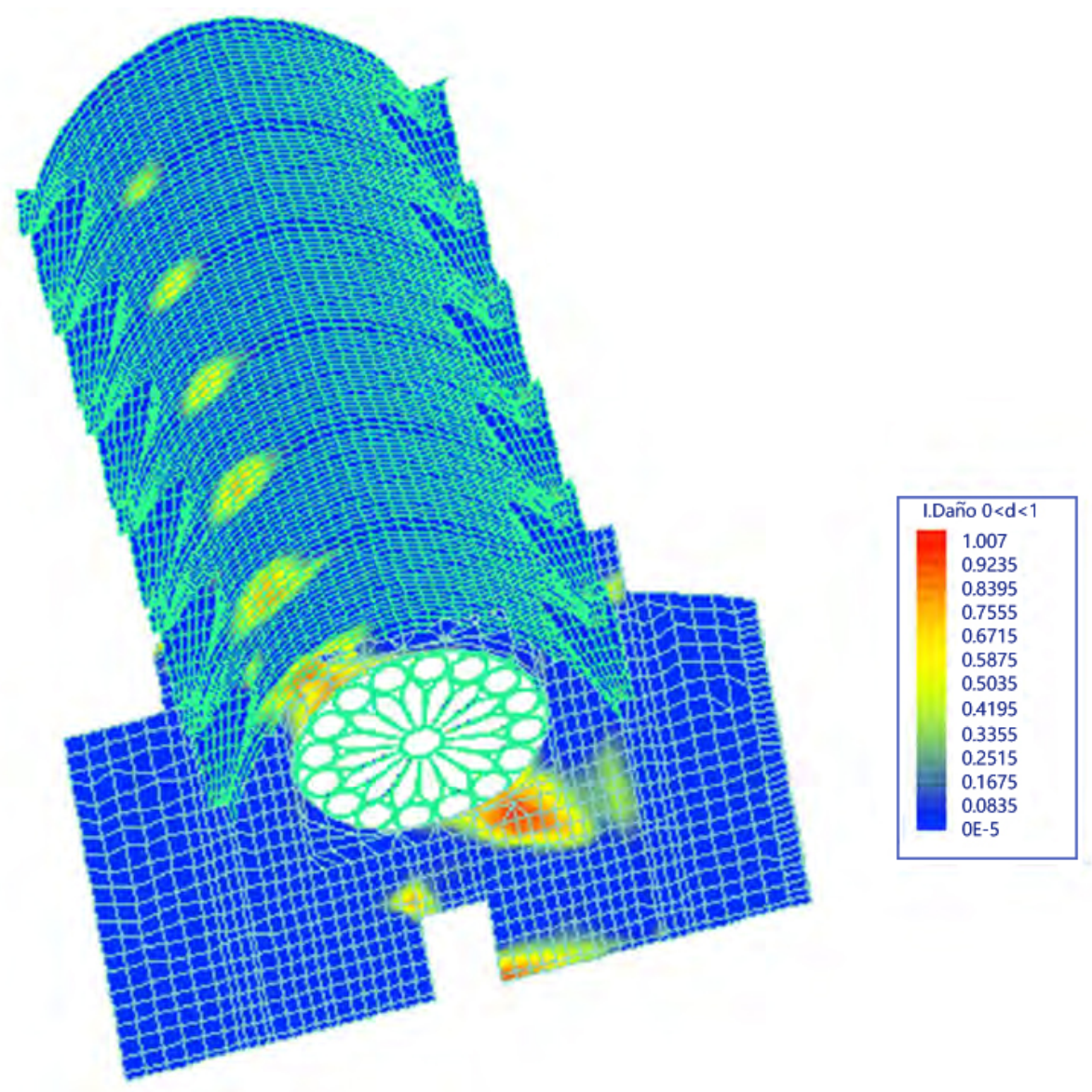

Figure 27. Damage index. 3D view

\section{Conclusions}

Some key findings can be drawn from the present study. The uncertainty of the origins of the oculus of the Santos Juanes Royal Parish Church required a detailed historic and structural analysis to find out why this structural element is walled in, which could have been a Gothic rose window. As we were unable to obtain conclusive results, we conducted a case study with two models: the first one with the current structural characteristics and a second one replacing the walled "O" with a Gothic rose window.

After performing an in-depth analysis of both models, a major stress concentration on the Z-axis of the bell tower mainstay when we compared this to the rest of the building. This proved that the bell tower plays a key role in the behavior of the church's wall structure, mainly on the "O" façade. Consequently, this façade would appear to be the weakest area for the building's dynamic stresses, with damaged areas that seriously undermine its stability.

Thus we verified that the damaged area of the calculation model exactly matched the real crack found, whose scope and depth are shown thanks to thermographic applications. When we compared the damaged area in both the walled model and the rose window one, the façade worsened in structural terms, which is the most vulnerable item in this set.
By way of conclusion, without being certain whether or not this rose window actually existed on the façade, all these findings indicate that this element's disproportionate dimensions, together with the wall's structural weakness mainly due to the presence of the bell tower, led to its removal and it was walled in for real reasons. Perhaps there was never any rose window because builders were afraid of it weakening the church's sturdy construction.

\section{REFERENCES}

[1] Medina Del Río J.M., Cassinello Plaza M.J., "La luz gótica. Paisaje religioso y arquitectónico de la época de las catedrales", Hispania Sacra, vol. 65 (EXTRA 1), pp. 95-126, 2013. DOI: https://doi.org/10.3989/hs.2013.017

[2] Yarza Luaces J., "Fuentes de la historia del arte I”, Ed. Historia 16, 1997.

[3] Huizinga J., “El otoño de la Edad Media”, Alianza Ensayo, 2001.

[4] Zaragozá Catalán A., "Iglesias de Arcos Diafragma y Armadura de madera en la Arquitectura Medieval Valenciana”, Thesis, Universitat Politècnica de Valencia, Spain, 1990. 
[5] Llopis Pulido V., "La Catedral de Valencia: construcción y estructura. Análisis del Cimborrio", Thesis, Universitat Politècnica de València, Spain, 2014. https://doi.org/10.499 5/Thesis/10251/39313

[6] Cassinello Plaza M.J., "Influencia de los Terremotos Históricos en la Construcción de las Catedrales Góticas Españolas”, Annali di Architettura: rivista del Centro Internazionale di Studi di Architettura "Andrea Palladio", no. 17, pp. 9-20, 2005. https://www.palladiomuseum.org/annal $\mathrm{i} / 2005 / 1$

[7] "Seismic map of Europe." [Online]. Available at: https://imageshack.com/f/9friesgossmicoeuropaj (accessed Sep. 12, 2015)

[8] "Rose Santa Catalina Church.” [Online]. Available: http://www.redjaen.es/francis/?m=c\&o=50844\&letra=\&ord =\&id=64613 (accesed Mar. 16, 2020).

[9] Danvila y Collado M., “Antigüedades de Valencia, por Fray Josef Teixidor, anotadas por D. Roque Chabás /Manuel Danvilla”. Boletín de la Real Academia de la Historia, vol. 28, 1896 in Alicante: Biblioteca Virtual Miguel de Cervantes, 2006.

http://www.cervantesvirtual.com/nd/ark:/59851/bmcms451

[10] Mas Tomás M.A., "Hacia una Metodología de Actuación en la Restauración de Edificios Construidos en Piedra”, Thesis, Universitat Politècnica de Valencia, Spain, 1990.

[11] Galarza Tortajada M., "El templo de los Santos Juanes de Valencia. Evolución histórico-constructiva”. Ed. Generalitat Valenciana, 1990.

[12] Cock H., "Relación del viaje hecho por Felipe II a Zaragoza, Barcelona y Valencia”. Real Órden por Alfredo Morel-Fatio y Antonio Rodríguez Villa, 1876. https://reader.digitale-sa mmlungen.de/de/fs1/object/display/bsb11333951_00007.ht $\mathrm{ml}$

[13] Eco U., “Arte y belleza en la estética medieval”, 2nd ed. Editorial Lumen, 1999.
[14] Estellés Ceba J.J., "Proyecto de Intervención de la Real Parroquia de los Santos Juanes de Valencia”. Conselleria de Cultura, Generalitat Valenciana., 1986.

[15] Vargas Alzate Y.F., Pujades Beneit L., Barbat Barbat H.A., Hurtado Gomez J.E., "Incremental dynamic analysis and pushover analysis of buildings. A probabilistic comparison", International Conference on Computational Methods in Structural Dynamics and Earthquake Engineering, Rodes, Greece, 2009, pp. 1-11. http://hdl.handle.net/2117/21186

[16] Alonso-Durá A., "BOVEDAS 3D, 3D graphical statics software.” Universitat Politecnica de Valencia, Spain, 2014.

[17] Alonso-Durá, A., “ANGLE, Structural Analysis Software for Finite Element.” 2015.

[18] Hanganu A.D., Barbat A., Oñate E., "Modelo constitutivo de daño isótropo" in Metodología de evaluación del deterioro en estructuras de hormigón armado. CIMNE no. 39, 1997, pp. 41-53.

[19] Hanganu A.D., Barbat A., Oñate E., Metodología de evaluación del deterioro en estructuras de hormigón armado. CIMNE no. 39, 1997. https://upcommons.upc.edu/bitstream /handle/2117/188171/428392.pdf

[20] Vacas Albala A., "Análisis sísmico de las catedrales góticas mediante el método del espectro de capacidad”, Master Thesis, Universitat Politècnica de Catalunya, 2009. http://hdl.handle.net/2099.1/8541

[21] Perelló Roso R., “Aproximación al comportamiento estructural de la iglesia y torre del monasterio de Santa María de la Murta” Thesis, Universitat Politècnica de València, 2015. https://doi.org/10.4995/Thesis/10251/57046

[22] Mouroux P., Le Brun B., "Presentation of RISK-UE project”, Bulletin of Earthquake Engineering, vol. 4, no. 4, pp. 323339, 2006. https://doi.org/10.1007/s10518-006-9020-3

[23] “Catalina Church.” [Online]. Available at: https://www.voy agevirtuel.net/espana/ecard/valencia-iglesia-de-santa-catali na-martir-6828.php. (accessed Mar. 15, 2020) 